\title{
AN OVERVIEW OF FISHERIES SECTOR OF BANGLADESH
}

\section{Mostafa Ali Reza Hossain*}

Department of Fisheries Biology and Genetics, Faculty of Fisheries, Bangladesh Agricultural University, Mymensingh-2202, Bangladesh

*Corresponding author: Mostafa AR Hossain, e-mail: marhossain@bau.edu.bd

\section{ARTICLE INFO}

\section{ABSTRACT}

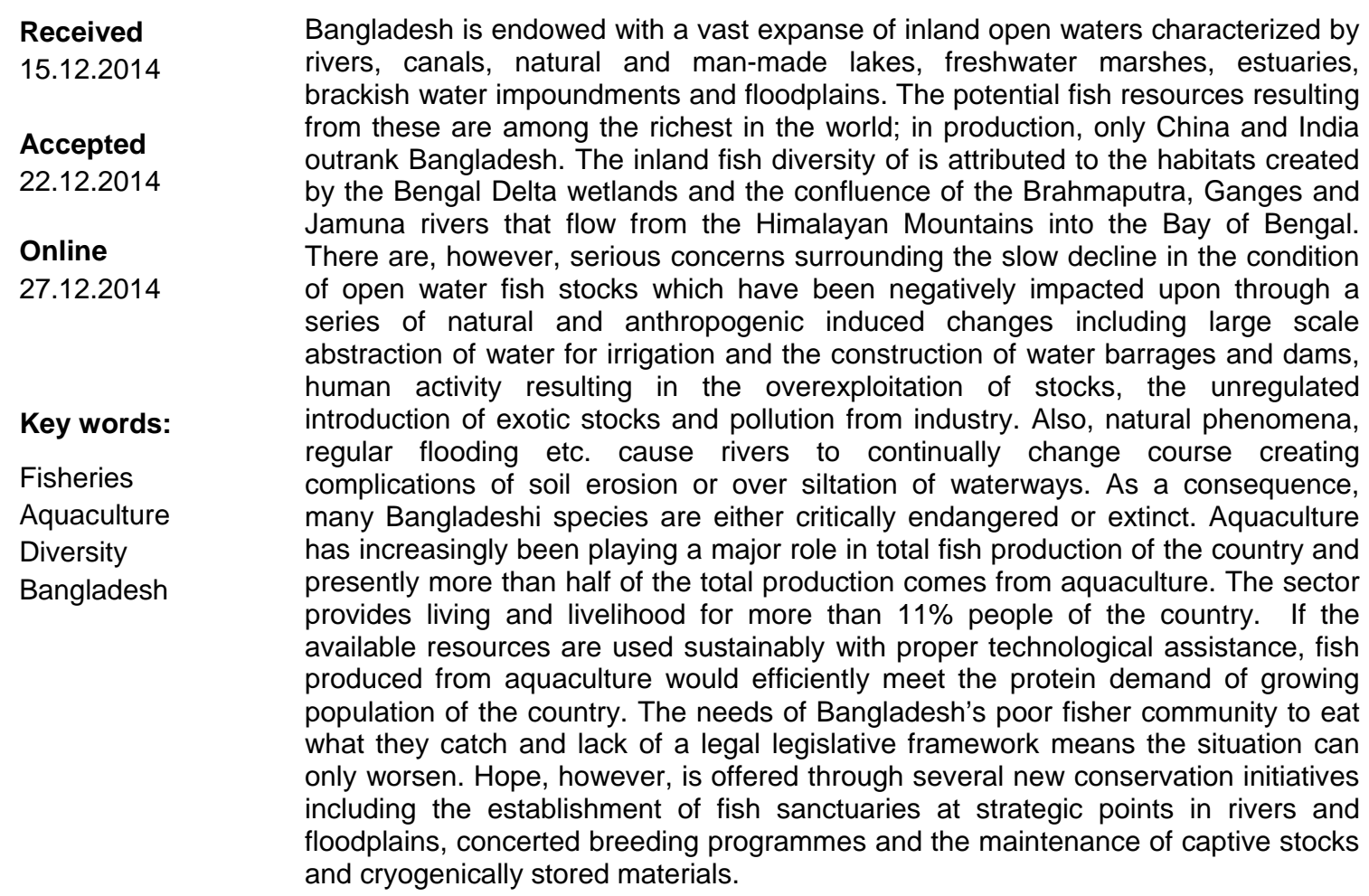

To cite this article: MAR Hossain, 2014. An overview of fisheries sector of Bangladesh. Res. Agric., Livest. Fish. 1(1): 109-126.

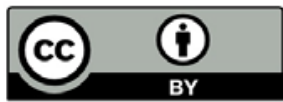

This article is an open access article licensed under the terms of the Creative Commons Attribution License.

www.agroaid-bd.org/ralf, e-mail: editor.ralf@gmail.com 


\section{INTRODUCTION}

Bangladesh is situated in the northeastern part of the South Asia and lies between $20^{\circ} 34^{\prime}$ and $26^{\circ} 38^{\prime}$ North longitudes and $88^{\circ} 01^{\prime}$ and $92^{\circ} 41^{\prime}$ East latitudes. The country is bordered by India on the West, North and North-East (2,400 kilometer land frontier) and Myanmar on the Southeastern tip (193 km land and water frontier). On the south is a highly irregular deltaic coastline of about 710 kilometers, fissured by many rivers and streams flowing into the Bay of Bengal. The territorial waters of Bangladesh extend $22 \mathrm{~km}$, and the exclusive economic zone of the country is $370 \mathrm{~km}$. The total landmass of the country is about $144,400 \mathrm{~km}^{2}$ and extends 820 kilometers north to south and 600 kilometers east to west. The country stretches out at the junction of the Indian and Malayan sub-regions of the Indo-Malayan zoogeographic realm. Formed by a deltaic plain, Bangladesh is virtually the only drainage outlet for a vast complex river basin made up of the Ganges (local name the Padma), the Brahmaputra and the Meghna rivers and their network of tributaries. The Padma unites with the Jamuna (main channel of the Brahmaputra) and later joins the Meghna to eventually empty into the Bay of Bengal. The alluvial soil deposited by these rivers every year has created some of the most fertile plains in the world. Most parts of the delta are less than 12 metres above the sea level, and it is believed that about $50 \%$ of the land would be flooded if the sea level rise by a metre. Straddling the Tropic of Cancer, Bangladesh has a tropical monsoon climate characterized by heavy seasonal rainfall, high temperatures, and high humidity. There are three broad physiographic regions in the country. It is a country dominated by wetland having more than $50 \%$ of its territory under true wetlands that is freshwater marshes, swamps, rivers estuaries and the world's largest contiguous mangrove forest -the Sundarbans.

Bangladesh has a total inland water area of 6.7 million ha of which $94 \%$ is used for open water capture fishery and $6 \%$ for closed water culture fishery. The inland open water fishery resources have been playing a significant role in the economy, culture, tradition and food habit of the people of Bangladesh. Rivers and their ramified branches cover about 479,735 ha area of land. Seasonal floodplain expands over a massive 5.5 million ha for 4-6 months of the year. Inland open water also contains estuarine areas with semi-saline waters (0-10 ppt), huge number of beels (natural depressions often with permanent area of water) and haors (bowl-shaped deeply flooded depressions) in the north and east and the manmade Kaptai lake-the largest lake of the country in the south. The country is blessed with 0.26 million of closed waters in the form of ponds, ditches, oxbow lakes (channel of dead rivers) and brackish water farms.

\section{FISH AND BANGLADESH}

In the globe, fish provides the best protein food rich in essential macro- and micro-nutrient, vitamins and minerals, Fish farming and fishing create working opportunity and income to millions of poor, and trade in fishery products play important role in poverty alleviation and economic growth of nations.

The fisheries sector, in Bangladesh, plays a particularly crucial role among poor as a main or additional source of employment, livelihood and income. The sector is the second largest part-time and fulltime employer in rural areas. It provides a crucial source of income and food to Bangladesh, and is second only to agriculture in the overall economy of the country. Fish is a natural complement to rice in the national diet, giving rise to the adage "Maache-Bhate Bangali", literally meaning - 'fish and rice make a Bangladeshi'. Bangladesh produced 3.26 million tons of fish during 2011-12 from inland and marine waterbodies and aquaculture contributed more than $50 \%$ of the total production. (Table 1) Fisheries accounts for $4.4 \%$ of Bangladesh GDP, $22.8 \%$ of agriculture sector and $2.5 \%$ of total export earnings. It also contributes $60 \%$ of the animal protein intake in Bangladesh, and even higher in populations living in the coast. 
Table 1. Fish Production of Bangladesh from different aquatic resources in 2011-12

\begin{tabular}{|c|c|c|c|c|}
\hline Water Resources & Water area (ha) & $\begin{array}{l}\text { Production } \\
\text { (MT) }\end{array}$ & $\begin{array}{l}\text { Production } \\
\text { (kg/ha) }\end{array}$ & \% Total \\
\hline Capture - Open Waters & $3,925,290$ & 957,095 & - & \multirow{6}{*}{29.34} \\
\hline River and Estuarine & 853,863 & 145,613 & 171 & \\
\hline Sundarbans & 177,700 & 21,610 & 122 & \\
\hline Beel & 114,161 & 85,208 & 746 & \\
\hline Kaptai Lake & 68,800 & 8,537 & 131 & \\
\hline Floodplain & $2,710,766$ & 696,127 & 257 & \\
\hline Culture -Closed waters & 774,055 & $1,726,067$ & - & \multirow{5}{*}{52.92} \\
\hline Ponds \& Ditch & 371,309 & $1,342,282$ & 3,615 & \\
\hline Seasonally cultured waters & 122,026 & 182,2930 & 1,494 & \\
\hline Baor (Ox-bow lake) & 5,488 & 5186 & 945 & \\
\hline Shrimp/Prawn Farm & 275,232 & 196,306 & 713 & \\
\hline Marine Fisheries & - & 578,620 & - & \multirow{3}{*}{17.74} \\
\hline Trawler & - & 73,386 & - & \\
\hline Aritasanal Fisheries & - & 505,2343 & - & \\
\hline Country Total & & $3,261,782$ & & 100 \\
\hline
\end{tabular}

DoF (2013)

The overseas fish trade is an important source of foreign currency earnings for the country and provides benefits at both the macro and microeconomic levels. Fish is the third largest contributor to Bangladesh's export earnings and is growing annually by 5-8 \%. Revenue from exports of nonfish agricultural goods is gradually being outpaced by fish products, to the extent that fish has become the most important primary commodity that Bangladesh exports (Dey et al. 2008).

Bangladeshi people largely depend on fish to meet their protein needs. Until 70s, there was an abundance of fish in the natural waters - the floodplain, rivers, rivulets, beels, lakes, ditches and canals of the country to well-satisfy the demand of fish. Presently, however, capture fish production has declined to about $50 \%$, with a negative trend of $1.24 \%$ per year. Despite the constant depletion of the natural water bodies for years, Bangladesh, globally, still holds one of the most diverse inland fisheries. However, the availability of many fish species has been drastically declined, and many are either critically endangered or regionally extinct. Both breeding and feeding migrations of the river and floodplain resident fishes of the country have been drastically cut off due to flood protection embankment with serious consequence on recruitment and production tonnage.

\section{KEY WATERBODIES AND THEIR STATUS}

The inland open water fishery of Bangladesh is composed of highly diverse and unique aquatic systems. It has an extensive network comprising of floodplains, large and small rivers, beels, haors and baors offering tremendous scope and potential for fish production. It has also large impounded water areas in manmade ponds, ditches, borrow pits, lakes and enclosures.

\section{The Floodplain}

Floodplains are relatively low laying land area, bordering rivers and seasonally over flooded by overspill from the main river channel. There are two distinct flooding patterns, one resulting in flow direction from the floodplains to the rivers (from flush flood due to local rainfall) and the other from 
the rivers to the floodplains (river overspill due to the heavy rainfall in the upstream). The ecodynamics of floodplain are influenced by the river water incursion and retreat and the timing and intensity of monsoon. There are great differences in the area flooded from year to year, and this greatly influences the population dynamics of many fish species. The seasonally flooded area is highly productive for growth of fish and other aquatic animals. During the dry season, as pasture land, the floodplain receives nutrients in the form of animal dropping and rotting vegetation. As the monsoon approaches the accumulated nutrients rapidly enters into the solution combined with river-borne silt, led to an upsurge of productivity resulting in rapid growth of plants and other forms of aquatic biota. This productivity phase offers an ideal condition for feeding and breeding of many riverine fishes and other aquatic animals which migrate to floodplain with the rising waters. Floodplains inundated during monsoons are nutrient rich and play a significant role as nurseries for larvae and juvenile of many fish species (Junk et al. 1989). A large number of fresh water fish species migrate from rivers and beels to floodplains for breeding and grazing and are harvested by the rural professional and amateur fishers. The floodplains are essential for most of the rural people of Bangladesh for their livelihood.

\section{The Rivers}

Bangladesh is a riverine country. It has numerous rivers and their tributaries. The Ganges, the Brahmaputra and the Meghna are the mighty rivers. The three rivers along with their innumerable tributaries form one of the richest habitats of fishes in the Indian Subcontinent. In addition to three main rivers, the other main rivers are the Karnafuli, Matamuhuri, Halda and Sangu in the southern Chittagong sub-region. The major rivers are the Surma, Kushiara, Kangsha and Someshwari in the north-east region and the Tista, Korotoa, Atrai, Bangalee, Mohananda in the north-west. The total length of the network of about 310 rivers in Bangladesh together covers more than 24,000 km with a catchment area of 1,031,563 ha. Annual flooding of the rivers inundates about $70 \%$ of the total land surface. The total annual discharge passing through the rivers system into the Bay of Bengal reaches up to 1,174 billion $\mathrm{m}^{3}$ (Banglapedia 2004). The rivers are not evenly distributed in the country. For instance, the numbers and size of the rivers gradually increase from the northwest of the northern region to the southeast of the southern region. All the rivers, except those of Chittagong hilly sub-region, belong to three major river systems, the Ganges, the Brahmaputra and Meghna. In the global context, the Brahmaputra is the 22nd longest $(2,850 \mathrm{~km})$ and the Ganges is the 30th longest $(2,510 \mathrm{~km})$ river in the world. Rivers and canals roughly cover $5.8 \%$ of the total area of the country. According to BWDB (2005), 57 of the rivers are trans-boundary -54 originate from India and 3 from Myanmar. During rainy season, the rivers carry high amount of silt which makes the water turbid. In winter, the water level decreases and water becomes clear. The depth of the coastal rivers usually ranges from $2 \mathrm{~m}$ to $5.5 \mathrm{~m}$ and reaches up to $36.5 \mathrm{~m}$ near the Bay of Bengal. Salinity of about 1 ppt extends nearly $56 \mathrm{~km}$ upstream in these rivers.

\section{The Beels}

The beel is a Bengali term used for relatively large surface, static waterbody that accumulates surface run-off water through an internal drainage channel (Banglapedia 2004). This type of shallow, seasonal waterbody is common in low-lying floodplain areas throughout Bangladesh. The total area of beels in Bangladesh was estimated to be 114,161 ha, occupying $27.0 \%$ of the inland freshwater (Ahmed et al. 2007). The number of beels in the north-eastern part of the country recorded was 6,034 having an area of 69,870 ha (Bernaesek et al. 1992). The most famous beel in the country known as the Chalan beel is located in the northwest. The other major beels in this region are Hilna, Kosba, Uthrail, Manda, Sobna and Beel Mansur. In central region, Arial beel and Balai beel now lost their importance as natural fish habitat. Other important beels in this region are Chanda, Boro, Mollar and Tungipara beels. There are many beels in the south and south west and 
the notable are Chapaigachi, Garalia, Panjiapatra, Chenchuri and Dakatia beels. The beels are parts of riverine floodplain formed due to changes in the river course or strengthening of river embankments for controlling flood (Saha et al. 1990). The beel water is very productive in terms of fertility and nutrient, full of organic debris and organic vegetation and provides food and shelter to many larvae and juvenile as well as adult fishes and other aquatic organisms (Graff 2003).

\section{The Haors}

The haors are back swamps or bowl-shaped depressions between the natural levees of rivers, or in some cases, much larger areas incorporating a succession of these depressions. The Bengali word haor basically derived from the word sagor (literally meaning sea) and dialectically sagor saior - haor has been evolved (Khan et al.1990). In terms of morphology and hydrology, a haor can be subdivided into three major areas, the piedmont area around the hill foot, the floodplains and the deeply flooded area (Hossain and Nishat 1989). The haors vary in size from as little as a few hectares to thousands of hectares. The haors flood to a depth of as much as $6 \mathrm{~m}$ during the rainy season and in many cases two or more neighboring haors unite to form a much larger water body. Greater part of the north east region of Bangladesh is characterized by the presence of numerous large, deeply flooded depressions, known as haors, between the rivers. There are altogether 411 haors (47 major and large sized) comprising an area of about $8,000 \mathrm{~km} 2$ dispersed in the northeastern Sylhet and Mymensingh districts. The haor basin is bounded by the several Indian states hills of Meghalaya on the north, hills of Tripura and Mizoram on the south, and the highlands of Manipur on the east. The two big rivers in the region - Surma and Kushiyara in association with several smaller hill-streams - Manu, Khowai, Jadhukata, Piyangang, Mogra and Mahadao form the dense network and supply the massive water to the haors. The rivers are primarily responsible for providing inputs - rainwater and sediment load to the haors. The haors remain flooded for about 7 to 8 months. During the rainy season, the haors look just like vast inland sea and the villages within appear as islands. In greater Sylhet the most prominent haors are Saneer, Hail, Hakaluki, Dekar, Maker, Chayer, Tangua and Kawadighi. In consideration of the environmental importance and heritage, the government has decided to save the Tanguar haor ( $9,500 \mathrm{ha}$ ) by symbolizing it as an internationally critical environment area under the Environmental Protection Law of 1995 and registered as a wetland of international importance (Ramsar site, site no. 1031, declared in 10.07.2000) under Ramsar Convention.

\section{The Baors}

In the southwest region of Bangladesh there are a number of meandering rivers changed their courses, part of the old course got silted up and cut-off from the main course. As a result horseshoe shaped oxbow lakes known as baor was created. A baor apparently looks like a lake, but unlike lakes, it remains connected with original river through channels during monsoon. This way, the baors annually receive fresh supply of riverine water carrying fry, fingerlings and adult fishes and other aquatic animals. Baors are very important wetlands of

Bangladesh and support a wide range of aquatic flora and fauna. There are more than 87 baors in Bangladesh covering an area of 5,488 ha (DoF 2008). Most of the larger baors are in southwestern Jessore region. The baors range in size from about 25 ha to a maximum of 500 ha (Bhuiyan and Choudhury 1997). The important baors of the country are Arial, Bahadurpur Baluhar, Bookbhara, Harina, Habullah, Rustampur, Ichhamati, Jaleshwar, Jogini Bhagini, Joydia, Kannadah, Kathgara, Khedapara, Marjat, Pathanpara, Rampur, Sagarkhali, Sirisdia and Sonadia.

\section{The Ponds and Ditches}

There are more than 1.3 million ponds having a water surface of 0.3 million ha in the country (DoF 2008). Though in past ponds were constructed for washing, bathing and irrigation purposes, 
recently, many ponds are being constructed absolutely for fish culture purposes. There are two types of ponds on the basis of water retention capacity - the perennial ponds - contain water round the year and the seasonal ponds - contain water at a certain times or seasons (mainly in monsoon). The pond culture fisheries have always been considered as being crucial for the livelihoods of the most vulnerable people of the country. In addition, it is also good for the fish diversity as it encourages the domestication of wild fishes through artificial breeding and rearing in the captivity. Selective aquaculture, however, could be detrimental for fish biodiversity as the culture technologies advice farmers to remove all small indigenous fishes from the ponds before releasing the fry of target fish. Farmers often use piscicide and insecticide to clean their ponds. The practice has been going on in Bangladesh since the carp polyculture being introduced in late 70s. As a result, though harvests from fish culture are rapidly increasing, the catches of small fishes are declining at an alarming rate.

\section{PRESENT STATUS OF FISH DIVERSITY}

Wild fish are declining for a variety climate change induced reasons. Most indigenous fish are migratory and rely on seasonal flooding for spawning cues and access to larval rearing habitat (floodplain). Almost all dams/embankment interfere directly with successful completion of fish migration (breeding and feeding). Agriculture (excessive removal of surface water and extraction of groundwater for irrigation), pollution (domestic and industrial), and unregulated discharge of untreated industrial and farm effluents, habitat destruction also have significant impact, as does lack of flooding/rain in last few decades. Once there were many isolated small depressions/water pools but those have since been converted into agricultural land. Since 1970, the annual flooding of approximately 2-3 million ha of floodplain has been either controlled or prevented altogether by means of sluice gates or pumps positioned along earth embankments or levees. This reduction in area is believed to be one of the major reasons for declining floodplain fisheries in Bangladesh. Introduced species are significant contributors to aquaculture production, but also threaten the biodiversity of indigenous fishes. In past, stocking of rivers and floodplain is carried out with both indigenous and introduced species by government and through different projects. The effectiveness of stocking activities has generally not been well assessed. Furthermore, the impacts of aquaculture (both commercial and small scale) have not been accurately assessed in this country.

The mounting pressure of the increasing demand for crop mainly rice to feed the hungry millions of Bangladesh is now being placed on the aquatic resources. The floodplains of the country are now among the fastest disappearing of all ecological systems. Fishing pressure from an ever-growing population has increased dramatically and has seriously affected the abundance of nearly half of the inland fishes of Bangladesh, particularly small fishes like minor carps, loaches, barbs, minnows, small catfishes, parchlets, gobies, featherbacks, snakeheads and eels. Most of the hill stream fishes of Bangladesh have either already been extinct or at the verge of extinction. As a whole, degradation of wetlands has caused several problems including:

- Extinction and reduction of fish and other wildlife

- Loss of many indigenous aquatic plants, herbs, shrubs and weeds

- Loss of natural water reservoirs and of their resultant benefits

- Increase in the occurrence of flooding

- Loss of natural soil nutrients and

- Degeneration of ecosystems, occupations, socio-economic institutions and cultures 


\section{THE MAJOR CAUSES OF LOSS OF FISH BIODIVERSITY}

In the past the major source of fish production in Bangladesh was the inland open water capture fisheries. During 1960s, it contributed about $90 \%$ of the country's total fish production. Rapid growth of population coupled with lack of proper management policy, however, created increasing pressure on fish resources and aquatic environment. Due to over exploitation of fish including use of harmful fishing gears and system (fishing by dewatering), degradation and loss of fish habitats, obstruction of fish migration routes by construction of embankment and water control structures mainly to increase agriculture production and road communication, siltation of water bodies by natural process, introduction of a number of alien invasive fish species and water pollution by industry, and agrochemicals, the natural inland fish stocks have declined significantly and fish biodiversity and poor fishers' livelihood have been affected seriously (Ali 1997).

Fish stocks in the rivers and floodplains are declining for a variety of reasons. Most of the indigenous fish are migratory and rely on seasonal flooding for spawning cues and access to larval rearing habitat (floodplain). Almost all dams and embankment interfere directly with the successful completion of the fish migration (breeding and feeding). Agriculture (excessive removal of surface water and extraction of groundwater for irrigation), pollution (domestic and industrial), and unregulated discharge of untreated industrial and farm effluents, habitat destruction also have significant impact, as does the regular overflooding and lack of flooding rain in the last few decades. Introduced species (primarily tilapia, Chinese carp and Thai pangas) are significant contributors to aquaculture production, but also threaten the biodiversity of indigenous fishes. In past, stocking of rivers and floodplain is carried out with both indigenous and introduced species by government and through different projects. The effectiveness of stocking activities has generally not been well assessed. Furthermore, the impacts of aquaculture (both commercial and small scale) have not been accurately assessed in this country.

Most of the literal and floodplains areas are cultivated with rice and other crops, providing multiple annual harvests. Thus, government policy has always prioritized cereal food production. Consequently, most development initiatives in the country have focused on crop cultivation, rather than biological management of the rich floodplain system for fish production, ignoring the needs of poorer people for access to renewable protein sources. Capture fisheries in inland waters which are based on natural productivity generally have reached the level of overexploitation. The inland open water fisheries, where the floodplains assume an important position in the livelihoods and nutrition of the rural poor have now been under serious threat of resource depletion due to various man-made and natural causes. The majority of the waters of this type have been depleted to an alarming state and warrant urgent interventions for conservation and sustenance. Ecosystem integrity has often been destabilized and aquatic systems now fail to support decent levels of aquatic life. As a result the livelihoods of fishers and rural Bangladeshis, previously supported by the inland open waters, are seriously compromised (Coates 1995). Some rivers and floodplains have been modified to a level where they are only recognized as narrow ditches and paddy fields.

\section{THE BACKGROUND OF AQUACULTURE IN BANGLADESH}

Aquaculture, in simple sense, is the farming of fish and other aquatic organisms, with 'farming' implying - some form of intervention to increase productions, and some form of private rights of the stock under intervention (Beveridge and Little 2002). Although livelihood opportunities associated with aquaculture contribute to the food security of large numbers of poor women and men, the direct effects of consuming fisheries products are of even greater significance.

Aquaculture or fish farming has been the most rapidly growing agro-food sector in the globe over the last four decades 1970 and 2010. Production of farmed finfish and shellfish has been 
growing at a rate of $8.1 \%$ per annum over this period. The aquaculture industry employs 23.4 million full-time workers globally, with Asia accounting for $92 \%$ of jobs. Aquaculture now provides around half the fish for direct human consumption and is set to grow further

The origin and developmental background of aquaculture practices in Bangladesh are not well documented. Historically, country's natural water bodies were stocked during the monsoon season through recruitment from natural spawning. Fish farming had been an age-old practice dating back a few centuries to when the country was ruled by Hindu kings. Many of the kings used to construct ponds and tanks for drinking, bathing and sometimes for small-scale irrigation, these ponds and tanks were also used for rearing fish although more from a recreation point of view than for commercial or nutritional purpose. Dr. Nazir Ahmed (1947-1960), the then Director of East Pakistan Department of Fisheries laid the formal foundation for fish culture in ponds and lakes in Bangladesh. He devotedly worked on the development of carp farming in ponds and beels and during the time between late sixties and early seventies considerable advancement were made in this area, eg., success in induced breeding of indigenous carp with pituitary gland extracts. Over the last few decades, however, fish habitats in Bangladesh have been degraded drastically by the development of flood control measures which resulted in a decline in natural fish production. As a result GOst, NGOs and private entrepreneurs have come forward to develop improved fish farming techniques especially in ponds and floodplains (FAO 2005).

There are two types of aquaculture practices are going on in Bangladesh - freshwater and coastal aquaculture. There is no marine aquaculture currently practiced in the country and no marine/coastal fin finfishes are farmed. Freshwater aquaculture comprises mainly pond farming of carps - (indigenous and exotic), Mekong pangasid catfish, tilapia, Mekong climbing perch and a number of other domesticated fish though in lesser scale. Coastal aquaculture is comprised mainly of shrimp and prawn farming in ghers (coastal pond or enclosures).

In Bangladesh, aquaculture production systems are mainly extensive and improved extensive, with some semi-intensive and in very few cases intensive systems. The present unit area aquaculture productions (MT/ha) are 3.6, 1.5, 0.95 and 0.71 for pond, seasonal waterbody, baor (oxbow lake) and shrimp gher, respectively. Inland pond culture represents the mainstay of aquaculture in Bangladesh, accounting more than $80 \%$ total recorded aquaculture production and presently dominated by carps (indigenous and exotic), Mekong pangas and tilapia.

\section{DOMESTICATION OF FISH FOR AQUACULTURE}

Domestication of wild fishes in most cases benefits both the fish farmer and the environment (Hossain, 2010). Investments in domestication have to pay off; therefore, researches should take into account the biodiversity and production scenario and overall socioeconomic and environmental outcome at a broader scale. In Bangladesh, to date about 20 fish species have been domesticated and their breeding and rearing protocols have been developed. Around $50 \%$ of the domesticated fishes are cypriniforms and now under nation-wide aquaculture (Table 2). Though there is high possibility of working with reduced gene pool, it is optimistically believed that the biodiversity of the domesticated fish are well-preserved.

\section{INTRODUCTION OF EXOTIC FISH IN THE NAME OF AQUACULTURE}

All over the world the exotic species have been recognized as an agent of the loss of indigenous biodiversity. Alteration of species and ecosystem caused by exotic invasive animals and plants influence the functioning and overall health of the affected ecosystems (Ameen 1999). As a country of rivers and wetlands, Bangladesh is very rich in fish diversity. Even then, over the last six decades a total of 24 fishes have been introduced (Table 3). The invasive species rapidly 
spread over the wetlands as biological explosives during the rainy seasons. Most of the introduced species were meant only for captive cultivation in closed pond systems but nobody succeeded to maintain the fish in captivity. During monsoon and/or flood the escapees easily found their ways to the rivers and floodplains throughout the country. This posed one of the major threats to the biodiversity of many indigenous fishes in this country.

Table 2. The domesticated indigenous fishes of Bangladesh

\begin{tabular}{|c|c|c|}
\hline Order & Fish & Culture status \\
\hline Cypriniformes & $\begin{array}{l}\text { Catla catla } \\
\text { Labeo rohita } \\
\text { Labeo gonius } \\
\text { Labeo bata } \\
\text { Labeo calbasu } \\
\text { Cirrhinus mrigala } \\
\text { Cirrhinus reba } \\
\text { Tor putitora } \\
\text { Puntius sarana } \\
\text { Lepidocephalichthys } \\
\text { guntea } \\
\text { Botia dario }\end{array}$ & $\begin{array}{l}\text { Country-wide commercial } \\
\text { Country-wide commercial } \\
\text { Country-wide commercial } \\
\text { Country-wide commercial } \\
\text { Small scale, sporadic } \\
\text { Country-wide commercial } \\
\text { Small scale, sporadic } \\
\text { Breeding protocol developed } \\
\text { Small scale, sporadic } \\
\text { Breeding protocol developed } \\
\text { Breeding protocol developed }\end{array}$ \\
\hline Osteoglossiformes & Chitala chitala & Small scale, sporadic \\
\hline Siluriformes & $\begin{array}{l}\text { Ompok bimaculatus } \\
\text { Ompok pabda } \\
\text { Mystus vittatus } \\
\text { Mystus gulio } \\
\text { Clarias batrachus } \\
\text { Heteropneustes fossilis }\end{array}$ & $\begin{array}{l}\text { Small scale, sporadic } \\
\text { Small scale, sporadic } \\
\text { Small scale, sporadic } \\
\text { Breeding protocol developed } \\
\text { Small scale, sporadic } \\
\text { Small scale, sporadic }\end{array}$ \\
\hline Synbranchiformes & $\begin{array}{l}\text { Mastacembelus armatus } \\
\text { Macrognathus aculeatus }\end{array}$ & $\begin{array}{l}\text { Breeding protocol developed } \\
\text { Breeding protocol developed }\end{array}$ \\
\hline Perciformes & $\begin{array}{l}\text { Anabas testudineus } \\
\text { Colisa fasciata }\end{array}$ & $\begin{array}{l}\text { Breeding protocol developed } \\
\text { Breeding protocol developed }\end{array}$ \\
\hline
\end{tabular}

Source: Hossain and Wahab (2009)

Several introduced species are highly carnivorous and predatory and eat almost everything including the small indigenous species of fish (SIS - which grow to a maximum length of 5- $25 \mathrm{~cm}$ (Felts et al. 1996). Several exotic species also compete with the SIS and gradually occupy their niches. The ecological, economic and biodiversity consequences of the introductions of exotic fish species have never been taken into consideration. It is very unfortunate that the long-term, and even short-term adverse effects were not considered while introducing the invasive species in Bangladesh. The excessive fecundity and growth rate of these species created pressure on the carrying capacity of the habitat, and the ecosystem balance itself by reducing the indigenous species diversity and population. Some of the negative impacts of exotic species on indigenous fishes are given in Table 4. 
Table 3. Exotic fishes introduced into the freshwaters of Bangladesh

\begin{tabular}{|llll|}
\hline Common name & Scientific Name & Source & $\begin{array}{l}\text { Year of } \\
\text { introduction }\end{array}$ \\
\hline Siamese gourami & Trichogaster pectoralis & Singapore & 1952 \\
Goldfish & Carassius auratus & Pakistan & 1953 \\
Tilapia & Oreochromis mossambicus & Thailand & 1954 \\
Guppy & Poecilia reticulata & Thailand & 1957 \\
Common carp & Cyprinus carpio & India, Nepal & 1960 \\
Mirror carp & Cyprinus carpio var specularis & India, Nepal & 1979 \\
Scale carp & Cyprinus carpio var communis & India, Nepal & 1965 \\
Leather carp & Cyprinus carpio var nudus & India, Nepal & - \\
Grass carp & Ctenopharyngodon idella & Hong Kong, & 1966 \\
Silver carp & Hypophthalmichthys molitrix & Hong Kong & 1969 \\
Nilotica & Oreochromis niloticus & Thailand & 1974 \\
Thai sarpunti & Barbonymus gonionotus & Thailand & 1977 \\
Bighead carp & Hypophthalmichthys nobilis & Nepal & 1981 \\
Black carp & Mylopharyngodon piceus & China & 1983 \\
African magur & Clarias gariepinus & Thailand & 1990 \\
GIFT & Oreochromis niloticus & Philippines & 1994 \\
Genetically improved & Cyprinus carpio var communis & Vietnam & 1995 \\
scale carp & & & \\
Thai pangas & Pangasius hypophthalmus & Thailand \\
Giant pangas & Pangasius gigus & Thailand & 1990 \\
Mosquito fish & Gambusia affinis & India & - \\
Sucker mouth catfish & Hypostomus plecostomus & Hong Kong & - \\
Red piranha & Pygocentrus nattereri & Singapore & 2003 \\
Pirapatinga & Piaractus brachypomus & Singapore & 2003 \\
\hline
\end{tabular}

Modified from Rahman (2005)

\section{PRESENT STATUS OF AQUACULTURE IN BANGLADESH}

An estimated 1.2 million people of Bangladesh are fishers and earn their livelihood from fishing. A further 12 million people indirectly earn their livelihood from fisheries and aquaculture and related activities, and employed in the backward and forward linkages of the value chain such as the downstream activities of fish trading, fish seed production, collection of shrimp and prawn seed, fish handling, processing and marketing, net making, input supply and processing. The number of fish farmers and shrimp/prawn farmers presently are 13.86 millions and 0.83 millions, respectively. Among the people involved in the sector $10 \%$ are women.

During 1960s, the inland capture fisheries contributed about $90 \%$ of the country's total fish production. Production from inland capture fisheries has declined significantly over the years and in 2010-11 it accounted only about 42\% (Fig. 1a). During 1960s, production from inland capture fisheries was almost 20 times higher compared to the then aquaculture production of the country (Fig. 1b). However, aquaculture production both in fresh water and brackish water has significantly increased during the last two and a half decades with development of technology. Due to the rapid increase of aquaculture production and sharp decrease of capture fishery production, in 2010-11, the aquaculture contributed (about $53 \%$ ) more than inland capture fisheries in total fish production of the country (DoF 2013). 
Table 4. The negative impacts of exotic fishes on the indigenous fishes

\begin{tabular}{|c|c|}
\hline Exotic fish & Impact \\
\hline Tilapia & $\begin{array}{l}\text { Their prolific breeding surpasses the carrying capacity of the waterbody leading to } \\
\text { stunting of tilapia and a number of SIS - mola, dhela, anju, darkina, chela, punti, } \\
\text { chapila, tengra, buguri, chanda, chikra etc. }\end{array}$ \\
\hline Common carp & $\begin{array}{l}\text { Destroy pond embankments, make water turbid by stirring up mud. Reduce the water } \\
\text { transparency and dissolved } \mathrm{O}_{2} \text { in water. Destroy habitat of SIS living closed to the pond } \\
\text { dyke and loaches in the bottom. }\end{array}$ \\
\hline Grass carp & High feeding competition with many herbivorous small and large indigenous fishes. \\
\hline Silver carp & $\begin{array}{l}\text { Strong feeding and habitat competition with- catla in both captive condition and in the } \\
\text { wild }\end{array}$ \\
\hline Thai sarpunti & Compete with local sarpunti for foods and space \\
\hline African magur & $\begin{array}{l}\text { Predation and voracity of this catfish is legendary, predate on almost all small and } \\
\text { medium fishes }\end{array}$ \\
\hline Thai pangas & $\begin{array}{l}\text { Natural diet is finfish, crustacean and insects, periphyton and benthos. This predatory } \\
\text { fish is the major cause of disappearance of SIS from the pond system }\end{array}$ \\
\hline Mosquito fish & $\begin{array}{l}\text { They live in the littoral zone of the waterbody and compete with small fishes for food } \\
\text { and habitat }\end{array}$ \\
\hline $\begin{array}{l}\text { Suckermouth } \\
\text { catfish }\end{array}$ & $\begin{array}{l}\text { One of the dangerous catfish, now found in floodplain allover country, feeds on small } \\
\text { crustaceans and fishes like loaches and freshwater eel }\end{array}$ \\
\hline Red piranha & $\begin{array}{l}\text { One of the most dangerous and aggressive species of piranha, feeds on insects, } \\
\text { worms and small and large fish. The cultured fish in the pond system and escapees in } \\
\text { the wild actively predate on the indigenous fishes particularly SIS }\end{array}$ \\
\hline Pirapatinga & $\begin{array}{l}\text { Natural diet is terrestrial plants, fruits, insects and crustaceans, however, in captivity } \\
\text { where natural food is scarce pirapatinga compete with SIS. The fish has strong, human } \\
\text { like teeth to crush food items. }\end{array}$ \\
\hline
\end{tabular}

Source: Hossain (2014)

\section{AQUACULTURE GROWTH}

Over the last three decades aquaculture in Bangladesh has expanded rapidly. Aquaculture has increasingly been playing a major role in total fish production (3.26 million tons) of the country and presently more than half of the total production $(52.92 \%)$ comes from aquaculture (1.73 million tons). Although farming of fish in this country, yet a low intensity semi-subsistence activity, rapid commercialization, gradual intensification and specialization have taken place over the last decade, leading to unprecedented expansion in production of farmed fish (Belton and Azad 2012). Horizontal expansion of aquaculture has been taking place on the riverine floodplains which have been enclosed to facilitate the intensification of production (Sultana 2012). Over the last couple of years, significant numbers of crop farmers have been converting their land to fish ponds, mainly in Mymensingh and part of Rajshahi, what many think a natural phenomenon related to ever decreasing benefit-cost ratio farmers are receiving from paddy farming. Aquaculture production of 33000 MT in 1960, increased to massive 1.73 million MT in 2012. Average annual growth (\%) of aquaculture is $10.81 \pm 1.79$ since 1990 to date. The annual growth rate was only negative during 2003-04 and so far highest in 1995-96 and 2008-09 (Fig. 2).

Production of aquacultured shrimp and prawn also increased significantly from a mere 14773 MT to 137,175 MT in 2011 (Fig 3). The \% contribution of farmed shrimp and prawn in total production is more than $60 \%$ and in recent years the wild catch has been gradually decreasing. The unit area production of farmed shrimp (300-700 kg/ha), however, is very low compared to fish produced in culture ponds. Mostly extensive form of culture is practiced to produce shrimp in gher and very few farmers practice even improved extensive method (Table 5). 

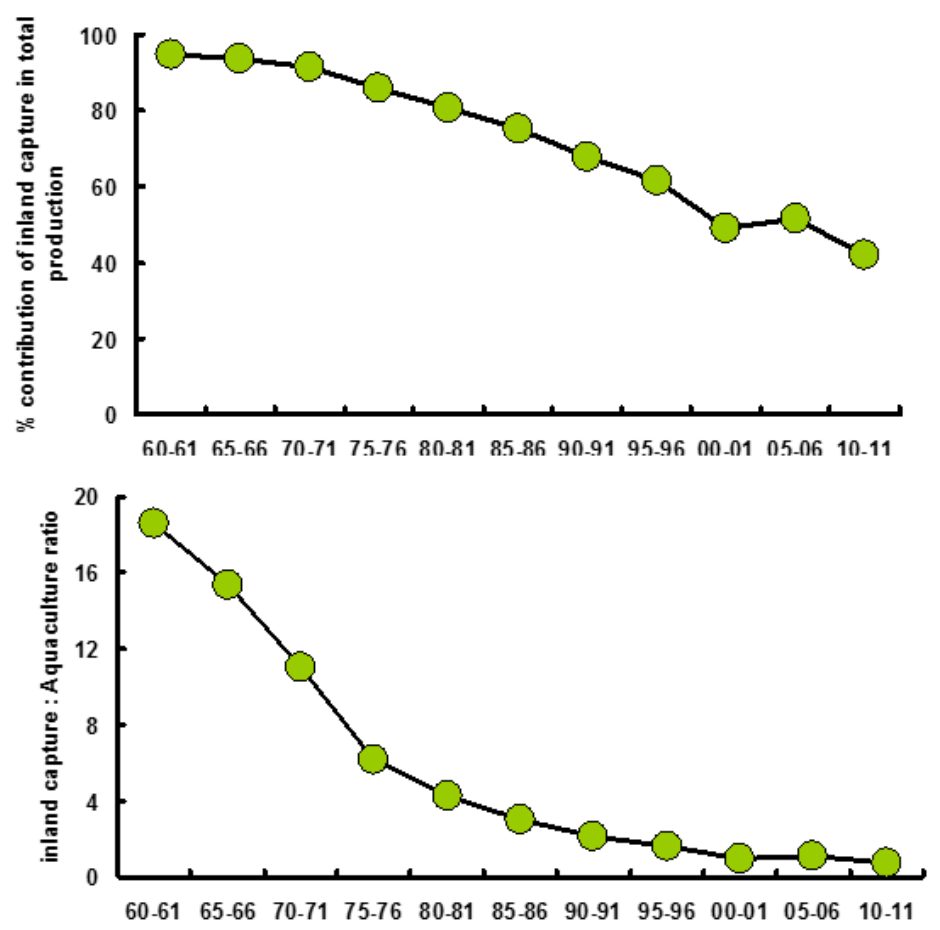

Fig. 1. Trend of fish production in Bangladesh 1960-2011

a. Contribution of inland capture (\%) in total fish production, and

b. Inland capture to aquaculture ratios Source: Ali et al. (2009); DoF (2013)
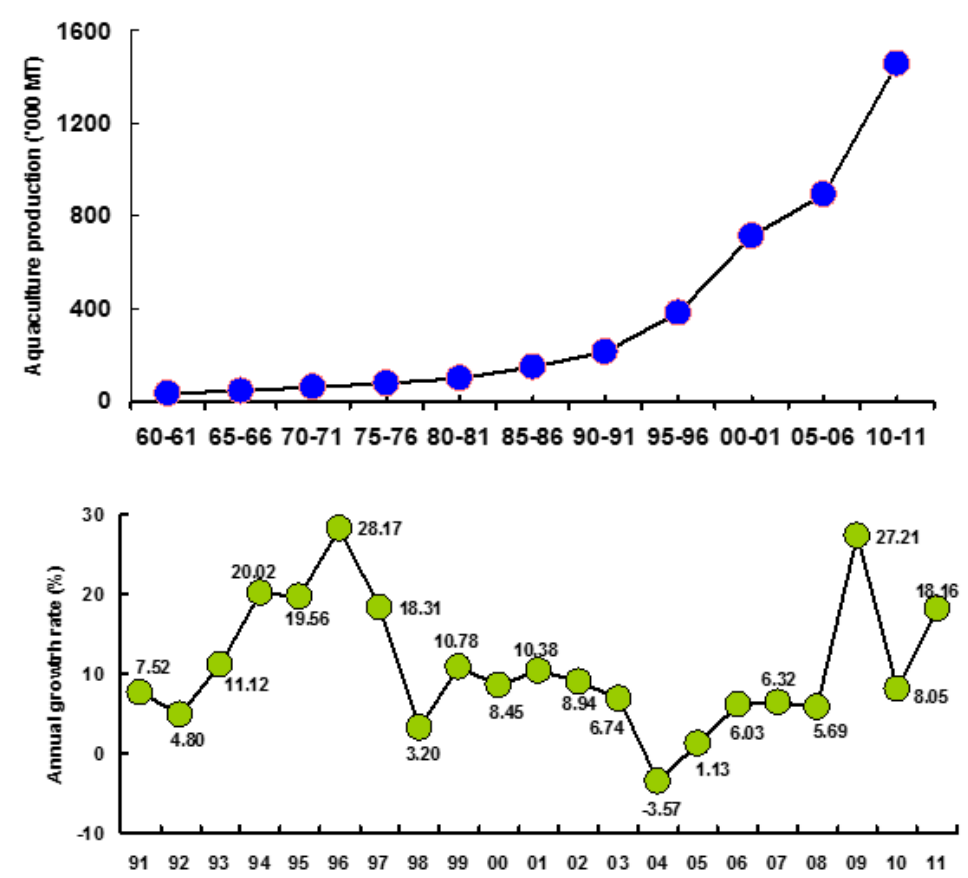

Fig. 2. Aquaculture growth in Bangladesh

a. The real value of aquaculture production ('000 MT) during 1960-2011

b. Annual growth rate (\%) of aquaculture during 1991-2011. Source: DoF (2013) 


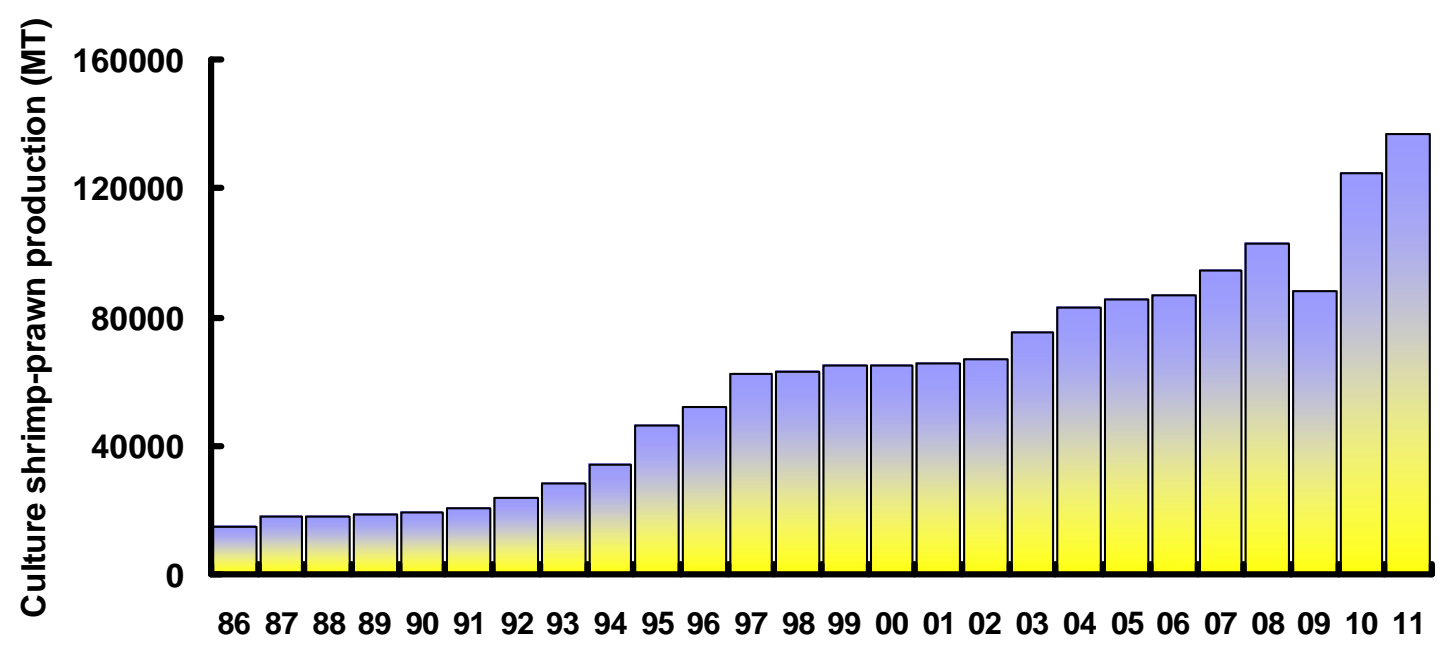

Fig. 3. Production of farmed shrimp and prawn in Bangladesh during 1986-2011

Table 5. Mode of shrimp culture in Bangladesh with production per unit area

\begin{tabular}{|c|c|c|c|c|}
\hline Species & Mode of culture & $\begin{array}{l}\text { Area under } \\
\text { culture (ha) }\end{array}$ & Management & Production kg/ha \\
\hline Bagda & Traditional (Extensive) & 190,080 & $\begin{array}{l}\text { PL stocking and water } \\
\text { exchange } \\
\text { (marine fish in the gher) }\end{array}$ & 300 \\
\hline Bagda & Improved extensive & 25,380 & $\begin{array}{l}\text { Dyke elevation; healthy \& } \\
\text { virus free PL stocking; } \\
\text { Supplemental feeding }\end{array}$ & $600-700 \mathrm{~kg}$ \\
\hline Galda & $\begin{array}{l}\text { Integrated } \\
\text { With rice, fish, } \\
\text { vegetables }\end{array}$ & Nearly 60,000 & $\begin{array}{l}\text { Little or no management } \\
\text { except PL stocking, } \\
\text { occasional feeding }\end{array}$ & $450-550$ \\
\hline
\end{tabular}

\section{AQUACULTURE LIVELIHOOD}

As the fish production from aquaculture has increased remarkably over the last few years, many poor and ultra-poor of rural areas of Bangladesh received the opportunity of fulltime and parttime employment to earn extra income. About $11 \%$ of the people of the country now directly or indirectly depend on the fish sector for their livelihood. Among the manpower associated with the fish sector, $10 \%$ are women ( $1 \%$ of total population). Moreover, $80 \%$ workers working for fish processing plants and fish drying centers are women. (DoF 2013; Hossain et al. 2013). Only during last 4 years, about 0.6 millions poor people found the work opportunity in the fish sector (DoF 2013). In Bangladesh, presently a total 14.7 million people have been involved in aquaculture in Bangladesh including fish farmers and prawn/shrimp farmers. The value chain from pond/farm to plate/fork and beyond the chain includes hundreds of stakeholders, whose livelihood fully depends on aquaculture. The major stakeholders include fish farmer, prawn/shrimp farmer, hatchery owner, nurserer, farm/hatchery technicians/workers, input (feed ingredient, fertilizer, hormone, chemical, instrument etc.) importers/suppliers, feed mill owners, homestead feed producer, fisher, fish processor, fish transporter, wholesaler, exporter, retailer, consumer, technology provider (government and non-government) and many more. 


\section{CLIMATE CHANGE IMPACTS ON OVERALL SETTING}

Bangladesh has been experiencing serious environmental degradation in recent years. In many respects, the situation has reached crisis proportions. Several factors make Bangladesh particularly vulnerable to environmental damage. There are many dimensions of this environmental degradation. Ground water contamination, surface water pollution, encroachment of rivers and water bodies, improper disposal of industrial, medical and household waste, deforestation and loss of aquatic habitat and bio-diversity are just a few examples. The fragile ecology, delicate flora and fauna, alarming density of increasing population, reliance on foreign aid and poverty of the masses are few such factors. Considerable damage has already been done. With loss of wetlands and forests, Bangladesh is gradually losing its flora and fauna. Many aquatic and territorial species are becoming rare; some have already become extinct. Bangladesh is most at risk from climate change. The country will face the greatest danger from global warming in the next 3 decades. Poverty and large low-lying coastal regions prone to annual floods and cyclones were among factors making Bangladesh the number 1 exposed country to climate change. Other most exposed countries in the continent are India, Nepal, Philippines, Afghanistan and Myanmar.

\section{CLIMATE CHANGE AND FISH SECTOR}

Climate change impacts gradually cover a wide range of livelihoods in a number of aquatic settings. Drought coupled with siltation and lowering water level are reducing over wintering habitat for indigenous fish species resulting into less recruitment into grazing field to grow inland fisheries. Reduced water flow in major rivers has resulted in a severe depletion of riverine fisheries. Due to decrease in groundwater and surface water, extreme pressure has been exerted on floodplains to convert them to crop filed, brick klin and other infrastructures, resulting in an alarming decline in fish diversity and production. Indeed, there may be nowhere in world where effects of climate change on fish sector are more apparent than in Bangladesh.

Bangladesh in 2009 witnessed the least rainfall in past one and half decade (since 1994) with scientists attributing the unpredictable pattern to global climatic change. During June - September, $2009,47,447 \mathrm{~mm}$ rainfall was recorded compared to $56,163 \mathrm{~mm}$ in the same period of 2008 , $66,520 \mathrm{~mm}$ in 2007 and $60,551 \mathrm{~mm}$ in 2008. On the other hand, excessive rainfall in several parts of country affected standing aman rice crops while less rainfall affected the major crop in some other areas. Average temperature of the country has been increasing slowly (Fig 4). More and more intense and long droughts have been observed since 1970s in almost all areas especially in northern Bangladesh. Water with poor quality and less availability for aquaculture and reduced production of fish are very common. Loss of both wild and farmed fish stocks has long been going on. There are conflicts among different water users and irrigation to crop fields always gets the priority.

\section{THE CONSERVATION MEASURES}

The government of Bangladesh and a number of non-government organizations (NGOs) have taken a number of regulatory and development interventions for sustainable management of the natural fisheries. In order to reverse the loosing trend and ensure sustainability of fish biodiversity and production from inland open waters various measures for protection, conservation and management of fisheries resources have been adopted time to time. Among the measures are the implementation of Fish Protection and Conservation Act 1950 and related rules including new fisheries management policy (licensing the fishing rights directly to the true fishers), community 
based fisheries management (CBFM), establishment of fish sanctuary in the strategic points of the rivers and floodplains, fish stock enhancement through releasing fish seed in seasonal floodplains, and fish habitat improvement through excavation of link canals (between rivers and floodplains) and beels. The Fish Act 1950 provides regulations for: (i) restriction on capture size of some fish for a specific period, (ii) restriction on catch of any species for specific time or season, (iii) closure of fishing in any water body for any stipulated time period, (iv) restriction of fishing by dewatering or any other destructive method, (v) restriction on the use of any kind of gear and mesh size of net, and (vi) restriction on placing fixed engine in a water course, which may restrict fish migration.

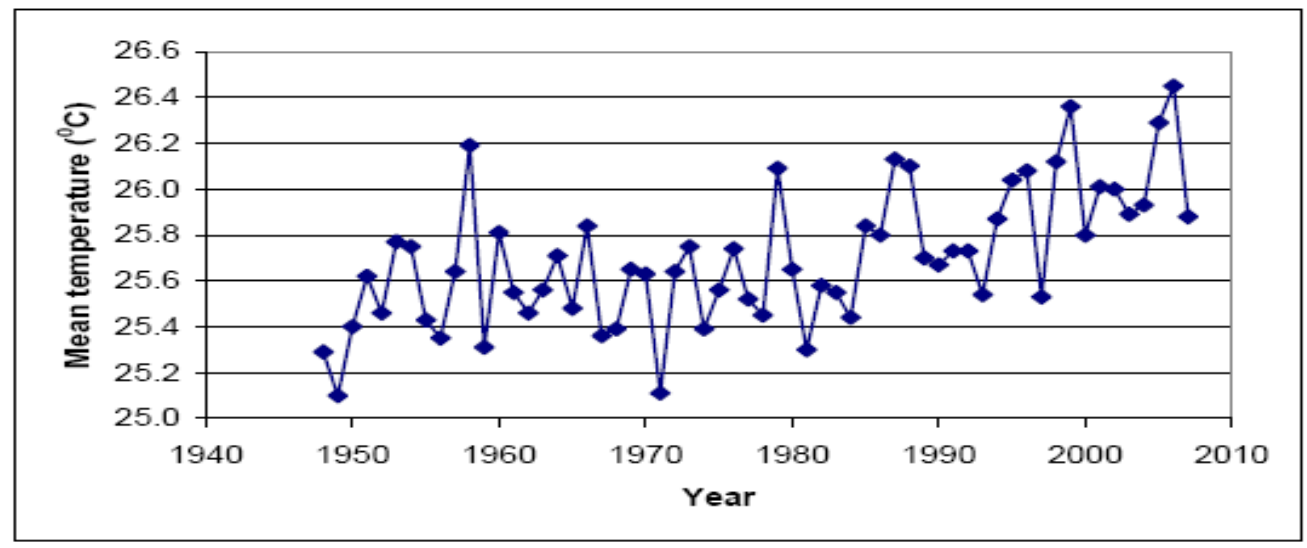

Fig. 4. Time series of all-Bangladesh annual mean temperatures 1948-2007 (CCC 2009)

Implementation of fisheries regulations has proved to be very difficult in this country due to institutional weakness of implementing authorities and the socio-economic conditions of the fishers. However, the Fish Act 1950 element - 'closure of fishing in specific area for specific period' as may be termed as 'fish sanctuary' is easier than applying other regulations of the Fish Act. Sanctuary has been tested and found as a powerful tool for protection and conservation of fish stock in Bangladesh. The dry season is the critical time for the fishes, when water levels in the rivers, canals, beels etc. recede drastically leaving a very few refuge for the inland fishes. Fish are exposed to greater predation and increased susceptibility to fishing pressure as the water level drops due to water extraction for irrigation and evaporation due to persistent heat of the dry season. Loss of surface water in the dry season results in the reduction in the brood fish stock. The fishes become increasingly vulnerable to intensive fishing and thereby the fish stock particularly the brood stock depletes to such a level that cannot sustain the fisheries and gradually fish diversity and production decline. Therefore, the major issue for biodiversity conservation is to provide sufficient dry season refuges to maintain the population at unstainable level.

Among all measures, fish sanctuary has been apparently found most effective for fish biodiversity conservation, when other measures are difficult to implement in the present administrative and social contexts. With this notion, Bangladesh government has established fish sanctuaries under different development projects following a number of management approaches since 1960 and more intensively in last decade. The NGOs like BRAC, CARITAS, CNRS, PROSHIKA and WorldFish Centre (CBFM project) have also been involved in fish stock development by establishing traditional sanctuaries in beels and rivers of Bangladesh. In addition, a number of silted up beels, baors, dead rivers and link canals have been re-excavated by the government under the food for work programs over the years. By 2000 a total of about 8,300 ha water area of borrow pit, baors, dead rivers, canals and beels had been excavated (DoF 2005). In the late 1990s the government approved a series of sectoral policies including National Fisheries Policy (1998), National Environment Policy (1995), and National Land Use Policy (2001) with a new 
emphasis on maintaining and protecting the moribund inland waterbodies. Under the National Fisheries Policy, government has formulated strategies for inland capture fisheries and emphasized on fisher community participation in fisheries management, along with fish sanctuaries as a key management tool (DoF 2005).

\section{CONCLUSION}

The crucial step for Bangladesh now is to address and integrate natural disaster and reduce risks into development plans and processes, to safeguard the nation's wellbeing and to secure and sustained the livelihood of people for both present and future generations. This must be addressed systematically so that the country recognizes the risks to development and change the way it plans to develop. There is a crying need to adjust the existing laws and legislation of the country for integrated resource management to save the fisheries resources. Although much of the damage to the habitat and biodiversity of the inland water of Bangladesh over recent decades is likely to be irreversible, there is still time to act. From now on, Bangladesh government, the NGOs and national and international bodies should foster a social and technical environment in which the enormous richness of the fisheries resources can stabilize and eventually rebuild so as to continue to feed people of today and tomorrow. Poverty in fishing communities should be reduced in part by ensuring a stable supply of fish, something can only be achieved through improved knowledge, integration of fisheries and freshwater management, and greater public involvement. In case of fishing closure in areas or for certain time, the fishers should be provided with alternative income generating activities, credit with low interest and other sustainable means. Creating public awareness of the importance of maintenance of fish diversity in Bangladesh is extremely necessary and should be the first priority for a lasting change. Sustenance of fish diversity can only be achieved with public support. Bangladeshi fishers, fish farmers, traders, processors, and general people as a whole need - to understand the issues, to be involved in the formulation of management plans and to benefit from the whole process. A key step in building fisheries comanagement and fish biodiversity conservation with community participation is to bring all the various stakeholders in a common front with a view to sharing resource and knowledge, creating an environment for meaningful discussion on cross-cutting themes and valuing each other.

A renewable resource like fish, when under intense exploitation, needs a management regime as it is not inexhaustible. Therefore, management measures should be applied in such a way that young fish are protected to grow before capture and enough are left as breeding stock for future generations. The management measures should include - regulate fishing intensity at sustainable level, control gear selectivity, gear type and size of fish, closed season, prohibition of destructive fishing, closed fish sanctuary, and allocation of resources to different types of fisheries. For sustainable and well-protected fish diversity for present and for future, the country should go for -

- Rational use of inorganic fertilizers and pesticides, and proper management of industrial effluents,

- Maintenance of minimum water depth (at least $1 \mathrm{~m}$ ) during water extractions from critical waterbodies,

- Regulation of selective fishing gears, mesh sizes, and fishing by dewatering,

- Establishment of more fish sanctuaries and natural beel nurseries in strategic points,

- Stock enhancement programmes,

- Establishment of community-based organizations (CBO) among the fishers,

- Zero tolerance to new exotic fish introduction, and

- Strict application of existing fisheries rules and regulations. 
This is the high time to care for the biodiversity of the indigenous fishes - the pride, heritage and livelihood of Bangladesh before they are lost forever. The researchers, policy makers, GOs and NGOs and national and international bodies should come forward to conserve the fish species using both in situ and ex situ approaches.

\section{REFERENCES}

1. Ahmed KKU, SU Ahamed, KR Hasan and MG Mustafa, 2007. Option for formulating community based fish sanctuary and its management in beel ecosystem in Brahmanbaria. Bangladesh Journal of Fisheries, (Special Issue), 30: 1-10.

2. Ali ML, MAR Hossain and MAhmed, 2009. Impact of Sanctuary on Fish Production and Biodiversity in Bangladesh. Final Project Report. Bangladesh Fisheries Research Forum (BFRF), Dhaka, Bangladesh. $80 \mathrm{p}$.

3. Ali MY, 1997. Fish, Water and People, Reflections on Inland Openwater Fisheries Resources in Bangladesh. The University Press Limited, Dhaka, 154p.

4. Ameen M, 1999. Development of guiding principles for the prevention of impacts of alien species. Paper presented at a consultative workshop in advance of the 4th meeting of SBSTTA to the CBD, organized by IUCN Bangladesh at Dhaka on 25 May, 1999.

5. Banglapedia, 2004. National Encyclopedia of Bangladesh, Asiatic Society of Bangladesh, 1st edn. February 2004, Dhaka, Bangladesh. Available from URL: www.banglapedia.org.

6. Belton B and A Azad, 2012. The Characteristics and Status of Pond Aquaculture in Bangladesh. Aquaculture, 358-359:196-204.

7. Bernacsek GMS, S Nandi and NC Paul, 1992. Draft Thematic Study: Fisheries in the North East Region of Bangladesh. North East Regional Water Management Project (FAP-6). Bangladesh Engineering and Technological Services, Dhaka, Bangladesh, 122p.

8. Beveridge MCM and DC Little, 2002. The history of aquaculture in traditional societies. In: CostaPierce, B.A. (Ed.), Ecological Aquaculture: The evolution of the Blue Revolution. Blackwell Science Limited, Oxford.

9. Bhuiyan AKMA and S N Choudhury, 1997. Freshwater aquaculture: potentials, constraints and management needs for sustainable development. National Workshop on Fisheries Development and Management in Bangladesh. BOBP/REP/74. Madras, India. 77-113p.

10. BWDB (Bangladesh Water Development Board), 2005. Bangladesher Nad Nadi, Pani biggyan, June 2005, Bangladesh Water Development Board, Dhaka. 621p.

11. CCC, 2009. Characterizing Long-term Changes of Bangladesh Climate in Context of Agriculture and Irrigation. Climate Change Cell, DoE, MoEF, Component 4b, CDMP, MoFDM. Month 2009, Dhaka.

12. Coates D, 1995. Inland capture fisheries enhancement: status, constraints and prospects for food security. Report of the International Conference on the Sustainable Contribution of Fisheries to Food Security, 4-9 December, 1995, Kyoto, Japan.

13. Dey MM, ML Bose and MF Alam, 2008. Recommendation Domains for Pond Aquaculture. Country Case Study: Development and Status of Freshwater Aquaculture in Bangladesh. WorldFish Center Studies and Reviews No. 1872. The WorldFish Center, Penang, Malaysia.

14. DoF (Department of Fisheries), 2005. Matshya Pakkhya Saranika-2005. Department of Fisheries, Ministry of Fisheries and Livestock. The Government of the People's Republic of Bangladesh, Ramna, Dhaka. Bangladesh. 109p.

15. DoF (Department of Fisheries), 2008. Matshya Pakkhya Saranika-2008. Department of Fisheries, Ministry of Fisheries and Livestock. The Government of the People's Republic of Bangladesh, Ramna, Dhaka. Bangladesh. 96p.

16. DoF (Department of Fisheries), 2013. Matshya Saptaha Saranika-2012. Department of Fisheries, Ministry of Fisheries and Livestock. The Government of the People's Republic of Bangladesh, Ramna, Dhaka. Bangladesh. $144 \mathrm{p}$.

17. FAO, 2005. National Aquaculture Sector Overview. Bangladesh. National Aquaculture Sector Overview Fact Sheets. FAO Fisheries and Aquaculture Department, Rome, Italy. 
18. Felts RA, F Rajts and M Akhteruzzaman, 1996. Small Indigenous Fish Species Culture in Bangladesh. Technical Brief, EC \& DoF, Integrated Food Assisted Development Project, Gulshan, Dhaka, Bangladesh. 41p.

19. Graaf GJ, 2003. The flood pulse and growth of floodplain fish in Bangladesh. Fisheries Management Ecology, 10: 241-247.

20. Hossain GM and A Nishat, 1989. Planning considerations for water resources development in the haor areas. AIT-BUET Workshops on Development and Technology, Bangladesh University of Engineering and Technology, Dhaka, Bangladesh. 12p.

21. Hossain MAR and MA Wahab, 2009. The diversity of Cypriniforms throughout Bangladesh: present status and conservation challenges. In: Tepper, G.H. (ed.), Species Diversity and Extinction. Nova Science Publishers Inc., New York.

22. Hossain MAR, 2010. Inland Fisheries Resource Enhancement and Conservation in Bangladesh. RAP Publication 2010/22. In 'Inland Fisheries Enhancement and Conservation in Asia' (eds. Miao, Silva and Davy), FAO Regional Office for the Asia and the Pacific, Bangkok, Thailand, pp 1-17.

23. Hossain MAR, 2014. Habitat and fish diversity: Bangladesh perspective, pp 1-26. In: Recent Advances in Fisheries of Bangladesh. Proc. of 5th Fisheries Conference \& Research Fair 2012. 1819 January 2012, Bangladesh Agricultural Research Council, Dhaka, Bangladesh Fisheries Research Forum, Dhaka, Bangladesh. 166 p.

24. Hossain MAR, B Belton and SH Thilsted, 2013. Preliminary rapid appraisal of dried fish value chains in Bangladesh. World Fish Bangladesh, Dhaka.

25. Junk WB, PB Bayley and RE Sparks, 1989. The flood pulse in river floodplain systems. In: Proc. International Large River Symposium (D. P. Dodge, ed.). Canadian Special Publication Fisheries Aquatic Sciences, 106:110-127.

26. Khan MA, KP Srivastava, R K Dwivedi, DN Singh, RK Tyagi and S N Mehrotra, 1990. Significance of ecological parameters in fisheries management of a newly impounded reservoir-Bachhara reservoir. In: Contribution to the Fisheries of Inland Open Water Systems in India (Part I) (eds. AG Jhingran, VK Unnithan and A Gosh). IFSI, Barrackpore, India. 100-108.

27. Rahman AKA, 2005. Freshwater Fishes of Bangladesh. Second edition, Zoological Society of Bangladesh, Dhaka, Bangladesh. 394p.

28. Saha SB, MJ Bhagat and V Pathak, 1990. Ecological changes and its impact on fish yield of Kulia beel in Ganga Basin. Journal of Inland Fisheries Society, 22: 7-11. 